University of Louisville

ThinkIR: The University of Louisville's Institutional Repository

\title{
Virginia's pursuit of self-government : the effects of the civil war and interregnum on England's first successful colony in North America, 1652-1660.
}

Lloyd Franklin Fowler

University of Louisville

Follow this and additional works at: https://ir.library.louisville.edu/honors

Part of the European History Commons, and the United States History Commons

\section{Recommended Citation}

Fowler, Lloyd Franklin, "Virginia's pursuit of self-government : the effects of the civil war and interregnum on England's first successful colony in North America, 1652-1660." (2014). College of Arts \& Sciences Senior Honors Theses. Paper 38.

http://doi.org/10.18297/honors/38

This Senior Honors Thesis is brought to you for free and open access by the College of Arts \& Sciences at ThinkIR: The University of Louisville's Institutional Repository. It has been accepted for inclusion in College of Arts \& Sciences Senior Honors Theses by an authorized administrator of ThinkIR: The University of Louisville's Institutional Repository. This title appears here courtesy of the author, who has retained all other copyrights. For more information, please contact thinkir@louisville.edu. 
Virginia's Pursuit of Self-Government:

The Effects of the Civil War and Interregnum

on England's First Successful colony in North America, 1652-1660

By

Lloyd Franklin Fowler

Submitted in partial fullfilment of the requirements

for Graduation summa cum laude

and

for Graduation with honors from the Department of History

University of Louisville

March, 2014 


\section{Table of Contents}

1. Introduction $\quad 3$

2. Chapter I: The Creation and Development of the General Assembly 10

3. Chapter II: Chaos Gripped England 19

4. Chapter III: Virginia's Solution to England's Crisis 38

$\begin{array}{lr}\text { 6. Conclusion } & 59\end{array}$

$\begin{array}{ll}\text { 7. Bibliography } & 64\end{array}$ 


\section{Introduction}

Virginia was established in 1607 at Jamestown and became the first successful English colony in North America - ultimately the foundation for the world's largest empire. Virginia's history in the seventeenth century has been well researched and analyzed by numerous historians. Surprisingly, however, a critical moment in the mid-seventeenth century has received much less attention: Virginia's unprecedented adoption of self-government between 1652 and 1660 in response to the chaos of the English Civl War and Interregnum.

For long stretches between 1642, the outbreak of the Civil War, and 1660, the ascension of Charles II on the English throne, Virginia's motherland sunk deep into political and social chaos. During that time, with the motherland embroiled in seemingly endless conflict and political turmoil, Virginia searched for some mode of political stability that could help the still fledgling colony to survive. ${ }^{1}$ The chaos in England during those years effected Virginia tremendously because its General Assembly needed a recognizable and stable sovereign to further increase the immensely profitable tobacco production and, inextricably linked to this goal, push the Native Americans in the Chesapeake region out of the way of the settlers and planters. The experiment with self-government between 1652 and 1660, a result of this search for stability, was an important precedent in the early history of the British Empire.

The colonial government in mid-century Virginia was comprised of the Governor and the General Assembly, which consisted of the House of Burgesses and the Council of State. From 1607 until 1652, the Council of State was the most powerful institution in the General Assembly because its members were directly appointed from England and the most elite men in Virginia

\footnotetext{
${ }^{1}$ Jon Kukla, Political Institutions in Virginia (New York: Garland Publishing, 1989), 205.
} 
were selected from England to sit on the Council of State. But in 1652, Parliament forced the colony to surrender to its rule and the newly-established English Commonwealth. The Commonwealth's take-over of Virginia flipped the balance of power not only within the General Assembly but also for the entire colonial government. ${ }^{2}$ A new constitution that year made the House of Burgesses the most powerful body. It now had the power to elect all public officers within the colony including the Governor and Councilors.

Unlike the Council of State, the House of Burgesses was a representative body which consisted of free male colonists elected by their constituents in the various counties and parishes. Until 1670, the House of Burgesses represented all free males without any land or tax requirements. ${ }^{3}$ In 1652, Parliament forced Virginia's surrender and empowered the House of Burgesses to rule Virginia as "representatives of the people." Imbued with this new power, the House of Burgesses took full advantage of the opportunity it presented to exercise this power between 1652 to 1660 to an extent that was not seen again until the American Revolution. It was in this way that Virginia's government dealt with the political turmoil arising in the Interregnum period.

The turmoil in England and the efforts to resolve it disrupted Virginia's tobacco trade, which was its life blood. Virginia's planters wanted political stability and a functioning government in order to facilitate stable commerce. Virginia's government struggled with the change of power from Charles I to the Commonwealth. This transition left a power vacuum in Virginia, which the House of Burgesses--taken advantage of the directions given by the

\footnotetext{
2 Warren Billings, A Little Parliament: The Virginia General Assembly in the Seventeenth Century (Richmond: Jamestown 2007/Jamestown-Yorktown Foundation, 2004), 34.

3 Ibid., 104.

${ }^{4}$ H.R. McIlwaine, Journals of the House of Burgesses 1619-1658/9 (Richmond: Virginia State Library, 1915$), 111$.
} 
Interregnum Parliament--filled in order to establish economic stability. The pursuit of a stable government in Virginia as a response to English political instability set Virginia on a trajectory towards self-government.

In order to understand and appreciate the radical steps that Virginia took with selfgovernment, it is necessary to gain an appreciation of the background of Virginia's government before the Civil War. The First Chapter provides this background with two periods of Virginia's early governmental history, which both proved crucial in the development of the Virginia General Assembly.

The first period was the time of Virginia's formation under the Virginia Company of London from 1607 to $1624 / 5$. During this period, Virginia was a joint-stock colony. The Company gave Virginia its local government, which by the end of this period consisted of a Governor, a Council of State and the House of Burgesses. These government structures were instituted at different times in order to help ensure the financial success of the Company, which was one of its primary objectives. The Company first tried autocratic rule through martial law, and it was at this time that Virginia's tobacco economy came into being. Some in the Company's leadership felt there was a better way to encourage further growth in Virginia's budding tobacco economy through a radical shift in government and economy. That shift came in the form of a free market economy through private land ownership and the introduction of representative government for the first time in the New World through the convening of the House of Burgesses in 1619.5 Mismanagement, the 1622 Indian Massacre and other financial problems prevented

\footnotetext{
${ }^{5}$ Billings, A Little Parliament, 12.
} 
these government changes from saving the Virginia Company, which in 1624 the Company succumbed to insolvency.

In 1624, Charles I revoked the Company’s charter and made Virginia a royal colony. The second period that was discussed in Chapter One was Virginia's time as a royal colony from this point through the execution of Charles I in 1649. During this period, the Crown's agents appointed the colony's Governor and Council of State but, otherwise, took a limited role in managing Virginia’s internal affairs. Thus, Virginia's government, but especially its colonial Governors, had the freedom to make significant changes to Virginia's government. In 1642, a critical government change was made after the arrival of Governor Berkeley. Up to that point, the House of Burgesses met with the Council of State as a single body. Berkeley split the two, and that split enabled the House of Burgesses to grow and to become the kind of body that took the actions that it would face in the Interregnum period. ${ }^{6}$

Chapter Two explains the turmoil that consumed England between 1642, which was the start of the Civil War, until 1660, which was the restoration of Charles II. The Civil War disrupted the settled order of Virginia's colonial affairs. Chapter Two explains the particular details of that war and the Interregnum that followed. The war arose over sectarian differences between Puritanism and Charles I's desire to have high Anglican religious uniformity. The Puritan controlled Parliament victory in the war lead first to the unprecedented execution of the King in 1649 and then a period of shifting governments known as the Interregnum. All of this turmoil created the power vacuum that necessitated Virginia's march towards unprecedented selfgovernment.

\footnotetext{
${ }^{6}$ Ibid., 27.
} 
It is the particulars of how that progression and evolution towards self-government occurred that is the subject of Chapter Three. When Virginia was forced to surrender to Parliament in 1652, Parliament's Commissioners directed the Virginia House of Burgesses to assume the mantle of leadership for Virginia. ${ }^{7}$ Parliament did little more, and Virginia was effectively left on its on. So, the House of Burgesses exercised its new found political power and progressively expanded self-government for the stability of Virginia's people and economy.

There are three points in time during the Interregnum that are significant for the expansion of this self-government. The first was Virginia's adoption of a constitution in 1652 that made the House of Burgesses the supreme power in the colony. The second event significant to this period was the Constitutional Crisis of 1658 in which the Council of State tried to subvert the House's supreme prerogative. The third and most expansive development came in 1660 when the Cromwellian Regime in England failed, which created a greater power vacuum causing the General Assembly to claim temporary absolute sovereignty.

This expansive power lasted until Charles II was restored to his throne in 1660 and brought back the restoration of the old order. These examples demonstrate Virginia's unprecedented and successful experiment with self-government during the Interregnum period.

$* * * \quad * * * \quad * * *$

Many historians have researched and written about seventeenth century Virginia history such as Philip Alexander Bruce who wrote Institutional History of Virginia in the Seventeenth Century, ${ }^{8}$ James Horn who authored A Land As God Made It: Jamestown and the Birth of

\footnotetext{
${ }^{7}$ William Waller Hening, The Statutes at Large; Being a Collection of All the Laws of Virginia from the First Session of the Legislature, In the Year 1619 Volume I (New York: R. \& W. \& G. Bartow, 1823), 517.

${ }^{8}$ Philip Alexander Bruce, Institutional History of Virginia in the Seventeenth Century Volume II (New York: G.P. Putnam's Sons, 1910).
} 
America,${ }^{9}$ Wesley Frank Craven who wrote Dissolution of the Virginia Company: The Failure of a Colonial Experiment, ${ }^{10}$ and Jack P. Greene who wrote Creating the British Atlantic. ${ }^{11}$

However, two specifically stand out above the rest in regards to the Virginia General Assembly between 1642-1660. Historians Warren Billings and Jon Kukla are the only historians who addressed the affects of the English Civil War (1642-1649) and the Interregnum (1649-1660) on Virginia in any detail. The most significant secondary source on this subject is Billings' A Little Parliament: The Virginia General Assembly in the Seventeenth Century. A second source, by a friend of Billings, was equally as helpful - Jon Kukla's Political Institutions in Virginia, 1619-1660. These two secondary sources helped tremendously with the proper interpretation of the primary sources. ${ }^{12}$

Critical primary sources for this thesis included H. R. McIlwaine's Journals of the House of Burgesses of Virginia 1619-1658/9.13 This source contained the transcribed abstract records of the House of Burgesses, which included committee reports, reading of bills, communications with the Council of State and other documents produced by the House of Burgesses. A second source, Hening's Statutes contained English copies of Virginia's statutory law from the colonial period. ${ }^{14}$ Third, Warren Billings collected Governor William Berkeley's papers in The Papers of

\footnotetext{
${ }^{9}$ James Horn, A Land As God Made It: Jamestown and the Birth of America (New York: Basic Books, 2005).

${ }^{10}$ Wesley Frank Craven, Dissolution of the Virginia Company: The Failure of a Colonial Experiment (Gloucester: Peter Smith, 1964).

11 Jack P. Greene, Creating the British Atlantic: Essays on Transplantation, Adaptation, and Continuity (Richmond: University of Virginia Press, 2013).

12 Billings, A Little Parliament: Kukla, Political Institutions in Virginia.

${ }^{13}$ McIlwaine, Journals of the House of Burgesses.

${ }^{14}$ Hening, Hening's Statutes.
} 
Sir William Berkeley, 1605-1677. ${ }^{15}$ This book provided the private correspondences of Virginia's Governor with Charles I and Charles II. Berkeley was governor of Virginia before and after Virginia's period of self-government.

In 1865, almost all of Virginia's seventeenth century records were destroyed by accident as the Union Army invaded Richmond, Virginia. As a result of this destruction, the largest portion of primary sources that exist today are English copies. Together, the Journals, Statutes and Papers open a window into Virginia's pursuit of self-government.

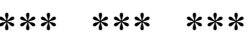

Virginia's successful attempt at self-government deserves further study because it was unique to Virginia's seventeenth century history. This thesis examines Virginia's history not as a separate entity, but as a colony that was linked to the events in England. Self-government proved a successful response by Virginia to England's crisis. The early history of the Virginia General Assembly in Chapter One provides a contrast and comparison with the events in Chapter Three. The story of England's crises and multiple different governments from 1642 thru 1660 paint a picture of chaos in Chapter Two. In Chapter Three, Virginia needed to have a functioning and stable government in order for counties to be formed, parish boundaries to be drawn, land disputes to be settled, and tobacco prices to be set. Virginia decided to satisfy its local needs through self-government.

${ }^{15}$ Warren Billings, The Papers of Sir William Berkeley 1605-1677 (Richmond: Library of Virginia, 2007). 


\section{Chapter I: The Creation and Development of the General Assembly}

It is important to explore and understand the Virginia General Assembly before the political instability in England began in 1642. Prior to the start of the English Civil War, the Virginia General Assembly developed and grew under both the Virginia Company of London and the Crown. These two political entities left their mark on the early history of the Virginia General Assembly.

In 1606, the Virginia Company of London received a charter from James I to start a colony in Virginia for the purposes of making money. As with any corporation, this company had a board of directors, which was known as the "Counsell of Virginia," with a "Treasurer" at its head. Pursuant to the original charter, the Council of Virginia was the governing body of both Virginia and the Company. James I created the Council of Virginia, which composed of thirteen men appointed by him, so that the Crown's interests were not neglected by the Company. A local Council of State in Virginia would then carry out the orders from the Council of Virginia in England and govern local affairs. Originally, the Council of State had a President, and its members were appointed by the Council of Virginia. ${ }^{16}$

Three years later, James I issued the Virginia Company’s 1609 Charter as part of its first reorganization effort. This second charter implemented the Council of Virginia's new changes and moved the location for government decisions to be made in Virginia. The most significant change abolished the office of President in favor of a Governor who was the head of the Council of State in the colony. The Council of Virginia recognized the logistical challenges of governing Virginia from England.

\footnotetext{
${ }^{16}$ Horn, A Land As God Made It, 37.
} 
The Council of Virginia wanted to impose stronger order upon the colony through the office of Governor, which started with Sir Thomas Gates in the 1609. In the "Instruccons Orders and Constitucons to Sr Thomas Gates Knight Governor of Virginia” the Governor received the authority to make laws as he saw fit that did not contradict his commission. ${ }^{17}$ This annexation of power from the Council of State to the Governor was significant in Virginia's history because it permanently shifted power from the Council of State towards the Governor for the next forty years.

The power of the Governor was too great though and this office created difficulty for the colonists in Virginia. Few colonists had the motivation to make Virginia a successful colony between 1611 and 1616 under Governor Sir Thomas Dale's harsh enforcement of the new law called "Lawes Divine, Morall and Martiall," 18 which was martial law. Recruitment of colonists was difficult because conditions under Dale were harsh and the colony's death rate was unsustainable. The land in Virginia was as harsh as its governor. Dale's government was heavyhanded, but he succeeded in whipping the colony into shape because Dale escalated Smith's policy of those "who will not work shall not eat."19

The Company needed the government in Virginia to not only help the colony survive, but to help the colony thrive in order to produce a profit. The second Treasurer of the Council of Virginia, Sir Edwin Sandys, recognized that colonists were needed if Virginia was to make a profit, and Dale's harsh tactics had to be stopped as well. By 1619, Sandys wanted to mitigate

\footnotetext{
17 Susan Myra Kingsbury, The Records of The Virginia Company of London: Documents I 1607-1622, Volume III (Washington, D.C.: US Government Printing Office, 1933), 12.

${ }^{18}$ Frank E. Grizzard, Jamestown Colony: A Political, Social, and Cultural History (Santa Barbra: ABC-CLIO, Inc., 2007), 60 .

${ }^{19}$ E. A. Benians, Captain John Smith: Travels History of Virginia (New York: Cambridge University Press, 1908), 210.
} 
the power of the colony's Governor through the House of Burgesses, which made the colony less autocratic in its approach towards governance. To potential colonists, the House of Burgesses was far more appealing to live under compared to Dale's rule and the martial law he imposed. ${ }^{20}$ In time, tobacco saved the colony and it was the harvest of tobacco that colonists were needed for because tobacco cultivation was a labor intensive crop. By 1614, the annual sale of tobacco in England reached $£ 320,000$ in profit. ${ }^{21}$ It was this demand that drove continued investments into the colony, so that it could replace the foreign producers who had hitherto supplied England. It was also this same demand for tobacco that required a government that met the needs of the tobacco planters and regulated the tobacco market. For instance, by 1631, tobacco production would be so regulated that the General Assembly set guidelines for the number of leaves allowed per plant. ${ }^{22}$ Sandys wanted a government structure in Virginia that not only incentivized these planters to make as much money as possible, he also wanted a proper government to regulate the planting and harvesting of tobacco in order to maximize the profits that tobacco generated.

Sandys created the House of Burgesses through the "Great Charter" of 1618, which was another restructure attempt and the colony's third charter. The Records of the Virginia Company of London document that, on July 30, 1619, the General Assembly approved the Great Charter. ${ }^{23}$ This approval established the House of Burgesses, the first representative body in the New World. Free white men in Virginia settlements elected one of their number as a burgess to

\footnotetext{
${ }^{20}$ Billings, A Little Parliament, 7.

${ }^{21}$ Horn, A Land As God Made It, 233.

${ }^{22}$ Hening, Hening's Statutes, 164.

${ }^{23}$ Kingsbury, The Records of The Virginia Company of London, 158.
} 
represent them in the House of Burgesses. The Company's desire to give Virginians more of a say in their local affairs was a innovative attempt by the Company to make Virginia profitable. Martial law under Dale limited production, which hurt the Company's profits. A new system of government was needed to create an incentive for colonists to work. The creation of a government structure that was democratic in nature within the Great Charter was a significant moment in the history of the Virginia General Assembly. In 1619, the House of Burgesses assembled with the Council of State to inaugurate the Virginia General Assembly.

The Council of Virginia used the General Assembly as a conduit to implement the orders of the Company. ${ }^{24}$ The Council of Virginia hoped that the House of Burgesses have improve the General Assembly's ability to implement these orders and directives. In the end, however, the House of Burgesses benefited the colonists more than the Company. The benefit that the colonists received from the House of Burgesses shaped Virginia's history throughout the seventeenth century long after the collapse of the Virginia Company of London. ${ }^{25}$

\section{The Collapse of the Company}

Mismanagement and the Indian Massacre of 1622 led to bankruptcy and combined to motivate Charles I to make Virginia a royal colony. The General Assembly, though, was retained in 1624 when James I dissolved the Virginia Company of London. The collapse of the Company was a turning point in the early history of the General Assembly because the General Assembly

\footnotetext{
${ }^{24}$ Billings, A Little Parliament, 12.

${ }^{25}$ Kukla, Political Institutions in Virginia, 5.
} 
underwent major changes after 1624. Understanding why these changes took place demonstrates the adaptability and durability of the Virginia General Assembly.

The Indian Massacre of 1622 was a complete failure on the part of the Company. It showed neglect and brought the Company's mismanagement issues further to light. The colonists and the Indians were already on a collision course when Englishmen first arrived in Virginia in May 1607. By 1622, the colonists settled on land up and down the James River that encroached on territory controlled by the Powhatan Confederacy. On March 22, 1622, Chief Opechancanough's surprise attack on multiple plantations killed 347 people out of less than 1,200: roughly a third of the population was killed in one morning. The Company leaders were outraged and baffled by the news of the Indian uprising and the massive loss of life. The slaughter of settlers was horrible news for the Company because it weakened the confidence of the stock holders. ${ }^{26}$ The leaders, as well as the colonists, were completely caught off guard..$^{27}$ To lose a third of the entire population in one day was the ultimate shock to council members and investors.

Before the massacre, the Company was on the brink of bankruptcy because of mismanagement. For example, the Company discouraged tobacco planting in favor of planting food even though tobacco generated profit. ${ }^{28}$ Sandys' plan for the colonization of Virginia was insufficient and lead to his failure as Treasurer. ${ }^{29}$ The Indian uprising's damage to the Company was bad enough, but the damage was amplified by its continued financial difficulties. ${ }^{30}$ The

\footnotetext{
${ }^{26}$ Horn, A Land As God Made It, 262.

${ }^{27}$ Ibid., 261.

${ }^{28}$ Ibid., 238

${ }^{29}$ Craven, Dissolution of the Virginia Company, 153.

${ }^{30}$ Ibid., 110.
} 
leaders were inadequate, incompetent and they had unrealistic expectations that wasted money. ${ }^{31}$ By 1616 , the Company was over $£ 9,000$ in debt because of its financial mismanagement. ${ }^{32}$ The problem was that the Company was not getting a return on its investment. ${ }^{33}$

The colonists' anxiety over the Company's mismanagement grew, especially after the Company failed to provide resources to fight the Indians. Settlers in Virginia were angry at the Company because they expected it to have provided some support. The Company was focused on profits more than support and Sandys' efforts failed to yield profit. ${ }^{34}$ The bankruptcy of the Company meant an end to the era of Company oversight of the Virginia General Assembly.

\section{The General Assembly Ruled By The King}

In November 1624, the Virginia General Assembly came under the control of the King when James I sued to revoke the Company's charter. James I wanted to prevent the abandonment of the colony because the Company failed to fulfill its promise of profit. The colony was under sound financial footing under the King's authority. He decided that the Council of Virginia was no longer capable of serving his interests and that he wanted to take direct control and authority over the colony and its General Assembly. However, the General Assembly never came under the control of James I, as his lawyers revoked the Company's

\footnotetext{
${ }^{31}$ Ibid., 110.

${ }^{32}$ Wesley Frank Craven, The Virginia Company of London: 1606-1624 (Williamsburg: Virginia 350th Anniversary Celebration Corporation, 1957), 37.

${ }^{33}$ Horn, A Land as God Made It, 232.

${ }^{34}$ Billings, A Little Parliament, 12.
} 
charter shortly before he died. James I's son, Charles I became King of England in March 1625. It was he who made the significant changes to the General Assembly after 1625 .

The transition that the General Assembly took from company oversight to royal oversight was awkward. James I died at a moment of transition for the Virginia General Assembly as the Assembly came under royal control. This transition was made more difficult by the fact that it took Charles I fifteen years to legitimize the General Assembly after he came to power. Seven weeks into Charles I's rule, he issued his Proclamation for setling the Plantation of Virginia. This declaration was an important milestone for the Virginia General Assembly because this document recognized Virginia as a royal colony. Charles I completed what his father had started before he died. However, Charles I omitted formal recognition of the Virginia General Assembly's right to exist as a lawful political body. ${ }^{35}$ This omission was a major problem for the General Assembly because it continued even with doubts of its own legitimacy and right to exist. ${ }^{36}$ Legitimacy was a persistent issue for the General Assembly, and it lobbied Charles I for formal recognition until he finally did so in 1639. For fifteen years, the General Assembly was an administrative tool that, out of inexperience, the King neglected to authorize. The transition to a new, distant sovereign was difficult.

Charles I's inattentiveness to the needs of the General Assembly early in his reign foreshadowed his inattention to the political needs of Virginia during the English Civil War. The General Assembly started to take shape because it evolved into a representative legislature. ${ }^{37}$ One reason that the General Assembly took on a legislative form was that the King was absent

\footnotetext{
${ }^{35}$ Ibid., 11.

${ }^{36}$ Ibid., 12.

${ }^{37}$ Ibid., 13.
} 
from Virginia's affairs, apart from the appointments of new Governors and Councilors. ${ }^{38}$ This freedom completed the Company's move of location for where government decisions were made from England to Virginia. Virginia had to take on more government responsibilities because Charles I left governmental affairs to Virginians.

The power vacuum in Virginia allowed the governor to be the most powerful influence over Virginia's politics and to fulfill the role of the central administrative figure. The royal governors shaped the development of the Virginia General Assembly because they ruled the colony. For example, Governor Sir Francis Wyatt instituted a new policy towards the Indians in roughly 1625 that was not part of his instructions from the King, but he used his power as governor to fight the Indians because he believed Virginia's success depended on ridding the Indians from the forest. ${ }^{39}$ The governor's powers under Charles I are worth remembering because these powers became associated with the office of Governor throughout the seventeenth century. Governors wrote land grants, issued pardons, appointed men to public office, were commander-in-chief of the militia and called elections for the House of Burgesses. However, one power that the governor did not retain after the execution of Charles I was the power to veto legislation passed by the General Assembly. ${ }^{40}$ The governors filled the executive void that Charles I left in the General Assembly.

By 1643 , Governor Sir William Berkeley used his powers as governor to change the Virginia General Assembly from a unicameral government to a bicameral government. This decision was the last major change before the start of the English Civil War. Originally, the

\footnotetext{
${ }^{38}$ Ibid., 13.

${ }^{39}$ Horn, A Land As God Made It, 281.

${ }^{40}$ Bruce, Institutional History of Virginia, 327.
} 
Virginia General Assembly consisted of the Council of State and the House of Burgesses that met together as one political body. However, the the merchant-planter faction lead by Richard Bennett, Samuel Mathews, Sr. and William Claiborne comprised the Council of State. This faction had close ties to England and wanted to monopolize the tobacco trade. They used their political positions as a business asset. The House of Burgesses composed the smaller planter elite that wanted to trade with the Dutch. The social stratification and political divisions between the two economic factions lead Berkeley to divide the General Assembly into a bicameral government in March 1643. ${ }^{41}$ The Council of State was the upper body, and the House of Burgesses was the lower body. ${ }^{42}$ As Governor, Berkeley provided institutional changes in order to meet Virginia's local need for a functioning government. Berkeley gave the General Assembly parliamentary form with two chambers because the split enabled the House of Burgesses to grow as an institution for the first time in ways that it could not have done previously.

The end result of this period was a Council of State, headed by the Governor that became the most powerful institution within the General Assembly. Berkeley put the General Assembly in a position to tackle the problems and issues that it faced throughout the English Civil War and the Interregnum. ${ }^{43}$ Both the Crown and the Company left its mark on the Virginia General Assembly prior to the start of the English Civil War.

\footnotetext{
${ }^{41}$ Billings, A Little Parliament, 36.

${ }^{42}$ Ibid., 36.

${ }^{43}$ Billings, A Little Parliament, 23.
} 


\section{Chapter II: Chaos Gripped England}

The English Civil War was a crisis for England. Historian David L. Smith encapsulated the turmoil in England when he wrote, "instead of being an instrument of the King's government, Parliament became an alternative government, claiming to defend the King's office even if this meant waging a war against the person of Charles I." ${ }^{44}$ This chapter explores what Parliament did to create the turmoil that gripped England from 1642-1660. Parliament was motivated, in part, by Puritan religious views that were in tension with the Laudian view held by Charles I. England experienced unexpected consequences rooted in this religious tension. As a result of this tension, the ancient traditional Lords, Commons and King political trinity was undone by the Civil War. The dissolution of the monarchy by Parliament and then Parliament's many failed attempts to create a successful Commonwealth translated into chaos that had ripple effects in Virginia. This political uncertainty in England created a power vacuum, which caused Virginia's experiment with self-government.

The chaos that consumed England in 1642 started with the sectarian divide between Puritans and high church Anglicans. ${ }^{45}$ The start of the Civil War was complicated and involved many factors, such as class differences and other grievances towards Charles I, but the sectarian divide was the major issue of contention. ${ }^{46}$ The Church of England consisted of both Puritans and Laudian high church Anglicans. The majority of the Members of Parliament were Puritans, which placed them at odds with Charles I.

\footnotetext{
${ }^{44}$ David L. Smith, The Stuart Parliaments: 1603-1689 (New York: Oxford University Press, 1999), 122.

${ }^{45}$ Nicholas Tyacke, Aspects of English Protestantism C. 1530-1700 (Manchester: Manchester University Press, 2001), 9 .

${ }^{46}$ Ibid., 8.
} 
Puritans were Calvinist and they wanted to reform the Church of England to emphasize the sermon over Church sacraments and rituals. Charles I followed the teaching of his Archbishop of Canterbury, William Laud. Laudianism encompassed what Laud taught, which emphasized the authority of church tradition and the sacraments over the teaching of the Bible. Laud influenced Charles I to continue the practice of both to the of bishops and to the use of the Book of Common Prayer within the Church of England, which Puritans opposed. ${ }^{47}$ Puritans despised Laud's views as too close to Catholicism and resisted Charles I's attempt at Church of England uniformity under Laud's leadership.

The Bishops' Wars of 1639-1640 in Scotland triggered a larger Civil War throughout Charles I's realm. Charles I forced bishops and high Church of England liturgy upon the Calvinistic Presbyterian Scots. This religious uniformity caused the Scots to rebel against the King. At the conclusion of the wars, Charles I had to pay for his army, which required the consent of Parliament to levy taxes. In November 1640, Charles I convened the Long Parliament for the purpose of levying taxes, but the Long Parliament refused to cooperate with Charles I until its grievances against him were addressed. This confrontation between the Long Parliament and Charles I triggered the Civil War. ${ }^{48}$

Parliament took advantage of this opportunity by stripping Charles I's power to dissolve them, but this political move by Parliament began the unraveling of the English government. Parliament decided to withhold money until Charles I addressed a list of 200 grievances called the "Grand Remonstrance." ${ }^{49}$ Parliament was last assembled in March 1629. So they used this

\footnotetext{
${ }^{47}$ Ibid., 205.

${ }^{48}$ Ibid., 176.

49 J. P. Kenyon, The Stuart Constitution 1603-1688: Documents and Commentary (Cambridge: Cambridge University Press, 1986), 207.
} 
opportunity well in order to speak out against Charles I. It was Charles I's unsatisfactory response to Parliament's redresses that led Parliament to turn hostile towards Charles I. This hostility towards Charles I lead the Long Parliament to pass the Act of Dissolution, which gave Parliament the power to give consent to the King's dissolution of Parliament. Hence, Parliament gained the ability to stay in session. Charles I signed this act in 1641 in order to get the funds he needed to pay for the Bishops' Wars. The members of the Long Parliament never expected that they would wage war on Charles I and then execute him. ${ }^{50}$

In January 1642, the tension between the Long Parliament and Charles I escalated into war when Charles I tried to arrest five members of Parliament. He accused these men of treason. ${ }^{51}$ The attempt to arrest them failed, and Charles I responded by fleeing London. When Charles I did so, he left a power vacuum, which the Long Parliament filled. The powder keg of grievances against the King and resistance to religious uniformity exploded into civil war. Parliament raised an army through the Militia Ordinance in March 1642.52 Charles I responded with an army of his own raised through an old system called Commission of Array.

It took a few months after Charles I fled London, but the first pitched battle happened on October 23, 1642 at Edgehill. Charles I was expected to rout the Parliamentarian Army, but the Puritan cause was given life because it fought tougher than expected. ${ }^{53}$ Both the Parliament and the King made decisions that escalated the tension towards greater warfare and divided an entire country.

\footnotetext{
${ }^{50}$ Smith, The Stuart Parliaments, 122.

${ }^{51}$ Kenyon, The Stuart Constitution, 217.

${ }^{52}$ Ibid., 219.

${ }^{53}$ Samuel R. Gardiner, History of the Great Civil War 1642-1649 Volume I (New York: AMS Press, 1965), 51.
} 
England was in chaos because Parliament challenged the King's authority, but the chaos was amplified when the Scots captured Charles I in January 1647, which ended the war. The Scots handed Charles I over to Parliament because Parliament wanted to use his imprisonment as leverage in negotiations on a settlement that both Crown and Parliament could agree to. ${ }^{54}$ Parliament believed that they had won a war and that Charles I should negotiate with them, but he refused to cooperate with the Long Parliament because he saw their actions as illegal. Charles I might have been defeated in battle, but he still considered himself King.

The Civil War resumed again in 1648 because Charles I enticed the Scots to invade England on his side by promising them religious reforms. The Scots switched sides when Charles I's promised to reverse his uniformity policy in Scotland. Charles I tried to use the Scottish invasion to restore his prior power and to prevent Parliament's impending complete take-over of the country. ${ }^{55}$ This activity was called the "Engagements with the Scots." 56 The Scots agreed to come to his aid and sent an army South, but in 1648 Parliament defeated the Scots at the Battle of Preston. This battle ended the second stage of the war and sealed Charles I's fate as a captive of Parliament. ${ }^{57}$

Charles I was a captive of the Long Parliament when the New Model Army purged Parliament and replaced it with the Rump Parliament. Parliament's actions destabilized the country and this anxiety translated into a struggle to find a post-war settlement that both Royalist and Parliamentarians could agree on. Smith argued that, "such anxieties had become very

\footnotetext{
${ }^{54}$ Samuel R. Gardiner, History of the Great Civil War 1642-1649 Volume III (New York: AMS Press, 1965), 353.

${ }^{55}$ Samuel R. Gardiner, History of the Great Civil War 1642-1649 Volume IV (New York: AMS Press, 1965),39.

${ }^{56}$ Ibid., 39.

${ }^{57}$ Ibid., 190.
} 
widespread by 1647-8 and many people deeply resented the frequent violations of legal and constitutional propriety that the Houses had committed in order to defeat the King." ${ }^{58}$ The New Model Army provided political stability and used the Rump Parliament as a front to its real power. Charles I was at the mercy of the Rump Parliament, which was controlled by the army. The Rump Parliament claimed absolute sovereignty through a resolution passed by the House of Commons on January 4, 1649. This resolution was a direct challenge to the authority of the captive King. The resolution stated:

Resolved, \&c. That the Commons of England, in Parliament assembled, do declare, That the people are, under God, the original of all just power: And do also declare, That the Commons of England, in Parliament assembled, being chosen by, and representing the people, have the supreme power in this nation: And do also declare, That whatever is enacted, or declared for law, by the Commons, in Parliament assembled, hath the force of law; and all the people of this nation are concluded thereby, although the consent and concurrence of king, or House of Peers, be not thereunto. ${ }^{59}$

Charles I was still alive and was unwilling to negotiate a post-war settlement because he still claimed to be sovereign. Two sovereigns cannot exist together at the same time and both rule over Virginia, let alone England. This transition from the King to the Commonwealth is important because the Commonwealth became the third entity to claim sovereignty over Virginia.

The Rump Parliament put Charles I on trial because his actions escalated the Civil War and his engagement with the Scots to invade England was treason. The Rump Parliament recognized that Charles I and his supporters would continue to find a way to take back power as long as Charles I was alive. The Rump Parliament wrote, "their remissness served only to encourage him and his accomplices in the continuance of their evil practices, and in raising new

\footnotetext{
${ }^{58}$ Smith, The Stuart Parliaments, 133.

${ }^{59}$ Kenyon, The Stuart Constitution, 292.
} 
commotions, rebellions and invasions." ${ }^{90}$ The monarchy was a threat, which amplified the chaos of the situation. Two institutions claimed sovereignty in England, but only one could truly be sovereign, which made Charles I's execution necessary for Parliament.

On January 6, 1649, the House of Commons passed an act titled, “The Act Erecting A High Court of Justice For the King's Trial."61 At the commencement of the trial, Charles called the legality of the court into question. Before the judges, he spoke to the constitutional chaos that people were afraid would grip England if the court ordered his execution. He argued before the high court that "the arms I took up were only to defend the fundamental laws of the kingdom against those who have supposed my power hath totally changed the ancient government."62 The Virginia General Assembly, in particular, resonated with the King's concern for overthrowing an ancient constitutional system. ${ }^{63}$ People wanted the chaos to end, not continue. However, the turmoil continued after the execution of Charles I.

The month of January moved quickly because the House of Commons claimed sovereignty; Charles I's trial court was created; and, then, on January 29, the high court signed Charles I's death warrant. Parliament executed Charles I the following morning outside the grandest palace in Europe, Whitehall, for treason. The high court ruled, "for all which treasons and crimes this Court doth adjudge that he, the said Charles Stuart, as a tyrant, traitor, murderer, and public enemy to the good people of this nation, shall be put to death by the severing of his

\footnotetext{
${ }^{60}$ Samuel R. Gardiner, The Constitutional Documents of the Puritan Revolution: 1625-1660 (Claredon: Oxford University Publisher, 1962), 357.

${ }^{61}$ Ibid., 357.

${ }^{62}$ Kenyon, The Stuart Constitution, 293.

${ }^{63}$ Hening, Hening's Statutes, 360.
} 
head from his body." ${ }^{96}$ Charles I claimed to be King of England until the very last moments of his life. The chaos that resulted from how the Commonwealth government handled the situation with Charles I throughout January 1649 foreshadowed the continued problems that would grip England and Virginia under the Commonwealth.

\section{Virginia During the English Civil War}

It is important to note that Virginia avoided the horrors and bloodshed of the English Civil War, but that did not mean that Virginia was removed from its uncertainty and chaos. In fact, the Civil War left Virginia abandoned by England, and this abandonment allowed the Virginia General Assembly to flourish and grow on its own. Parliament and Charles I in England had each other to worry about and had no time to address the far removed colonies, such as Virginia. ${ }^{65}$ However, England's abandonment during the Civil War lead to two problems for Virginia. First, Charles I wanted Virginia Governor William Berkeley to force religious uniformity on Virginia. Second, Virginia had its own war to fight with the Powhatan Indians in 1644, and Charles I was unable to help Virginia with that war. Virginia might have been far removed from the fighting in England, but Virginia felt the effects of the Civil War.

In 1643, Berkeley arrived in Virginia as the new governor, and he carried with him personal instructions from Charles I to enforce an Oath of Allegiance to the Church of England and to kick nonconformists out of the colony. Charles I instructed Berkeley to create religious

\footnotetext{
${ }^{64}$ Gardiner, The Constitutional Documents of the Puritan Revolution, 380.

${ }^{65}$ Warren M. Billings, Sir William Berkeley and the Forging of Colonial Virginia (Baton Rouge: Louisiana State University Press, 2004), 89.
} 
uniformity in Virginia by "administering the Oaths of Allegiance and Supremacy to all such as come thither, with intention to Plant themselves in the County which if he shall refuse he is to be returned and shiped from thence home." ${ }^{\prime 6}$ Charles I wrote to Berkeley that he wanted, "the preservation of the puritie of doctrine and unitie of the church." ${ }^{97}$ Virginia was not immune from Charles I's passion for religious uniformity, and it could have easily been detrimental to Virginia.

Berkeley wanted to avoid the bloodshed and not commit one of Charles I's biggest mistakes. Virginia was a place where not all practiced high church Anglicanism, which was what Charles I wanted. Virginia had a major shortage of priests, which stunted any desire to have high church Anglicanism practiced in Virginia on a regular basis across the colony. The animosity between Puritans and Laudians was not replicated in Virginia. ${ }^{68}$ The high church Anglicans in Virginia were relaxed in their worship, which also aided Virginia's resistance towards punishing nonconformists. Berkeley might have plunged Virginia into the same bloodshed that Charles I plunged England into if Berkeley had enforced Charles I's instructions, but he did not want to repeat the Bishops' War of 1639-40. So, Berkeley steered Virginia away from conflict, but it was the Natives who kept Virginia out of the sectarian civil war.

On April 18, 1644, the Indians attacked the colonists in a similar manner as they had done in the 1622 Massacre. Opechancanough planned the attack for Maundy Thursday, a special day for Christians in Holy Week leading up to Easter, because he knew of the religious significance of that day for the English. He had hoped that the settlers would be vulnerable that day because they would all be observing the religious day. Also, Opechancanough knew that Virginia had a

\footnotetext{
${ }^{66}$ Kukla, Political Institutions in Virginia, 127.

${ }^{67}$ Ibid., 127.

${ }^{68}$ Billings, A Little Parliament, 29.
} 
new Governor and that England was in the midst of a Civil War. Opechancanough wanted to maximize all these different factors in order to dislodge the colonists from Virginia. ${ }^{69}$ The surprise attack was a resounding success, but it did not dislodge the settlers as Opechancanough had hoped. However, over 500 colonist were killed in one day, and the surprise attack threw the colony into a two-year war with the Indians.

An anonymous Virginia Puritan mentioned that it was the surprise Indian Massacre of 1644 that preoccupied Virginia from fighting a sectarian civil war in Virginia. The anonymous Virginian said that a month before the massacre, Puritans were being asked to take the Oath even though Berkeley wanted to avoid sectarian violence. The Virginia Puritan noted that Opechancanough, the Powhatan Indian Chief, would have had a greater impact if had waited a month longer for sectarian tension to grow in Virginia. ${ }^{70}$ Opechancanough's attack gave Puritans and high church Anglicans something to rally against instead of fighting each other.

Virginia was now disengaged from the Civil War in England, and they needed arms to fight the Indians. Opechancanough wanted to dislodge the colonists from Virginia, which meant that Virginia needed weapons. The General Assembly sent Berkeley to England in order to seek aid from Charles I. Berkeley placed the leading member of the merchant-planter faction, William Claiborne, in charge of the army during his absence to carry out the war, and be appointed the Secretary of the colony, Richard Kemp, the acting Governor. ${ }^{71}$

Upon Berkeley's arrival in England in the Fall 1644, he discovered England in conflict. This turmoil made Virginia's situation worse. Now, Virginia could not depend upon England.

\footnotetext{
${ }^{69}$ Billings, Sir William Berkeley and the Forging of Colonial Virginia, 96.

${ }^{70}$ Kukla, Political Institutions in Virginia, 128-129.

${ }^{71}$ Billings, A Little Parliament, 28.
} 
Virginia would have to learn how to fend for itself. A precedent was set when Berkeley bought weapons back with him to Virginia. Virginia had to find a solution to its own problems because England was preoccupied with Civil War. Charles I's situation was too desperate for England to provide assistance in fighting the Indians, and Virginia was too remote to help. All of Charles I's weapons were needed in England to fight the Parliamentarians. ${ }^{72}$

In 1645, Berkeley left England and arrived back in Virginia. He discovered that the war with the Indians had gone poorly under Claiborne's leadership. Berkeley soon led Virginia militia to victory, when he sprung a trap on Opechancanough's forces and captured the Indian chief. A Jamestown colonist bayoneted the Indian Chief while he was a prisoner of war. The death of Opechancanough ended the war, and the General Assembly ratified a peace treaty with the Powhatans in October 1646. The struggle against the Indians unified the Virginians because they no longer cared how they worshiped, when their safety was at stake. ${ }^{73}$ England's absence in the fight against the Indians was a problem that the Virginia General Assembly had to solve on its own through its own solutions.

\section{The Parliament's Approach to Virginia}

The Interregnum was a period between the execution of Charles I on January 30, 1649 and the Restoration of his son Charles II on May 29, 1660. This period of history created further political uncertainty for Virginia. England's political institutions changed often after Charles I's execution. The first change in government occurred when England became a Commonwealth

\footnotetext{
72 Ibid., 97.

${ }^{73}$ Ibid., 104.
} 
ruled by a Council of State. ${ }^{74}$ Further uncertainty was created in England when Charles II tried to gain the throne at the unsuccessful Battle of Worcester in 1651. Charles II was the son of Charles I and was his heir and successor to the throne. Before this defeat, he was a constant threat to the Commonwealth. He went into exile in Breda, Netherlands until 1660, when he was invited by Parliament to be King of England. ${ }^{75}$

Virginia was further isolated by England after its source of legitimacy, the King, was executed in 1649. The General Assembly did not know if it had a right to exist with the King dead and Charles II in exile. Between 1649-1651, Parliament was unable to provide a solution to Virginia's legitimacy issue because its attention was focused on Charles II, not Virginia. Parliament took Charles II threat to its new power seriously. This period was difficult for Virginia because Berkeley kept Virginia loyal to Charles II even though he had no power in England

Charles II no longer posed a threat to Parliament's power after he was defeated by the New Model Army at the Battle of Worcester in 1651. This victory freed Parliament to send a fleet to Virginia in order to address colony's disloyalty. ${ }^{76}$ In 1652, Parliament forced Virginia to surrender to the Commonwealth and to give up its allegiance to Charles II. Parliament accomplished Virginia's surrender through commissioners that it sent to Virginia to force its cooperation and to make it submit to the authority of the Commonwealth. Virginia always turned to England for its political authority, but Berkeley refused to submit to Parliament with

\footnotetext{
${ }^{74}$ Gardiner The Constitutional Documents of the Puritan Revolution, 384.

${ }^{75}$ Ibid., 465.

${ }^{76}$ W. Noel Sainsbury, Calendar of State Papers, Colonial Series, 1574-1660 (London: State Department of Her Majesty's Public Record Office, 1860), 361.
} 
Charles II still alive. ${ }^{77}$ Berkeley made Parliament force Virginia into the Commonwealth in order to show his loyalty to Charles II.

Parliament approached Virginia's submission to its authority in two separate ways. Parliament's two approaches added to Virginia's political uncertainty because these decisions brought Virginia further under Parliament's control. The first approach was the Navigation Act of 1651, which allowed Virginia to trade only with England. The second approach was Parliament's forced political surrender of Virginia's General Assembly through four commissioners that it sent to Virginia. Both approaches happened almost simultaneously, as intended by Benjamin Worsley who was Secretary of the Commonwealth's Council of Trade. This council focused on the colonial issues as a sub-committee of the Council of State. ${ }^{78}$

First, the Navigation Act of 1651 removed the Dutch as trading partners with Virginia, which hurt the smaller planters. The larger merchant-planters dominated the tobacco trade with England and left no room in the English market for smaller planters. Parliament was unable to control Virginia completely until Virginia had severed economic ties with the Dutch. Parliament perceived the Dutch as an economic threat if it had to share tobacco profits with the Dutch. Parliament believed that it was easier to empower the Virginia elite that already traded exclusively with England and force Virginia's submission through economic means. ${ }^{79}$

Second, in 1651, Parliament appointed four commissioners, Robert Dennis, Richard Bennett, Thomas Stegge and William Claiborne who were Virginians loyal to Parliament and who happened to be in England. Parliament gave them the task of forcing Virginia's surrender to

\footnotetext{
${ }^{77}$ Billings, The Papers of Sir William Berkeley, 106.

${ }^{78}$ John Spurr, Anthony Ashley Cooper, First Earl of Shaftesburry 1621-1683 (Farnham: MPG Books Group, 2011), 113.

${ }^{79}$ Billings, A Little Parliament, 30.
} 
the Commonwealth. With this position, they enforced the Navigation Act and instituted a new colonial government in Virginia. Also, the four Commissioners used this position of authority to make the new colonial government favorable towards their business interests. These four men benefited from their relationship with Parliament and Parliament benefited from their loyalty.

On September 26, 1651, the Council of State issued instructions to four Virginians to reduce Virginia into submission to Parliament. The instructions that Parliament gave to the four commissioners were important because the 1652 Virginia Constitution's authority was rooted in this document:

Instructions for Capt. Robt. Dennis, Richard Bennett, Thos. Stagg, and Capt. Wm. Claybourne, Commissioners for reducing Virginia and the inhabitants thereof to their due obedience to the Commonwealth. To repair on board the John or the Guinea frigates, and sail to Virginia, as Capt Dennis shall direct. To use their best endeavours to reduce all the plantations within the Bay of Chesapeake. Power to assure pardon and indemnity, and to make exceptions; to use acts of hostility in case the inhabitants submit not by fair means; to appoint captains, raise forces in any of the plantations, and set free those serving as soldiers, if their masters stand in opposition to the present government. To publish acts of Parliament against Kingship, the House of Lords, and for abolishing the Book of Common Prayer. Power to administer the engagement, to allow burgesses chosen by the planters who take the engagement to meet for government of their affairs. Directions for the issue of writs, warrants, \&c. In case of the death of Capt. Dennis, Edmund Curtis, commander of the Guinea frigate, to command the fleet. Encouragement. [Emphasis Added $]^{80}$

Virginia's now had the authority from England to exist. It had sought this approval since Charles I's execution in 1649. This new authority that the House of Burgesses had set Virginia on a path towards self-government. Parliament only cared to have Virginia's submission, not to micromanage the colony. ${ }^{81}$

\footnotetext{
${ }^{80}$ Sainsbury, Calendar of State Papers, 361.

${ }^{81}$ Ibid., 361.
} 
Parliament wanted to remove Virginia as a pocket of disloyalty toward the Commonwealth. After the Commonwealth achieved Virginia's submission, it was incapable of involving itself in Virginia's affairs. The army never brought complete stability to England after 1652, which prevented England from focusing on Virginia. Parliament changed too often and the army, which had the real power in England, did not care about Virginia.

\section{Parliament's Continual Constitutional Failures}

It was, of course, the Rump Parliament that executed the King in January 1649. The Rump Parliament did not abolish the House of Lords until February 6, 1649, and it also did not abolish the monarchy until 17 March 1649. Parliament created the Council of State to rule as the executive in England on February 13, 1649. As Kenyon wrote, "the process of constitutional revision was ragged and haphazard, and it was not until 19 May that an act was passed declaring England to be 'a Commonwealth or Free-State."”82 Parliament never had a stable government after 1649 because Parliament struggled to have a settled constitutional plan. As isolated as Virginia was, the lack of government in England that could properly rule gave it more room and indeed the need for self-government.

One reason stability was never achieved was because the army (the Council of Officers) instigated change in 1652 when it demanded immediate dissolution of the Rump Parliament in order to implement a plan of voter proportionment distribution devised in $1647 .{ }^{83}$ Instead, Oliver Cromwell negotiated a termination date of November 3, 1654. Cromwell was the commander of

\footnotetext{
${ }^{82}$ Kenyon, The Stuart Constitution, 296.

${ }^{83}$ Blair Worden, The Rump Parliament (Cambridge: Cambridge University Press, 1974), 142.
} 
the New Model Army, and he embodied the principles of the Puritans in England as the leader against Charles I. After 1649, Cromwell directed all of Parliament's major decisions because Cromwell lead the New Model Army, which held the political power in England. The dissolution of the Rump Parliament by the army and Cromwell's involvement in Parliament was evidence that the army used Parliament as a front. Both Cromwell and the army were primary factors in Parliament's continued instability. ${ }^{84}$

The Rump Parliament tried to hold new elections in April 1653, in order to stay in session beyond the agreed date. Cromwell acted on 20 April 1653 when he lead soldiers into Westminster to expel the Rump Parliament by force a year before the negotiated end date. A contemporary remarked at Cromwell's take over: "[it] no doubt struck a popular chord, and the events of 1647-1653 had consistently shown that [Parliament] was unwilling to effect the fundamental reforms of the constitution." 85 Cromwell's popularity because of his war victories and the Rump Parliament's disapproval because of its inaction prevented any upheaval that might have occurred due to Cromwell's unconstitutional maneuvering. He was well aware of the potential consequences of the forced dissolution of the Rump Parliament.

Now, Cromwell and the generals saw themselves as the supreme authority because they realized that they had the power to call elections. Even with this new power, Cromwell still faced mutinies in the judiciary and uprisings by royalists. The constitutional experiments were unending in England. Between April to July of 1653, England was ruled by Cromwell because he was the leader of the army. ${ }^{86}$ These few months did not have a Parliament and was the

\footnotetext{
${ }^{84}$ Kenyon, The Stuart Constitution, 299.

${ }^{85}$ Ibid., 299.

${ }^{86}$ Ibid., 300.
} 
beginning of Cromwell's military dictatorship of England. Even before the Rump Parliament lost power, Parliament had to have the support of the army in order to rule England. ${ }^{87}$

Cromwell was made "Lord Protector" in December 1653 by the army. He ruled England from 1653 until his death in 1658 . He had the power to call new parliaments, but, he became the de facto sovereign. The "Instrument of Government" was the new constitution of England as approved only by the House of Commons. It was a new constitution for England to help ensure long-term stability after Cromwell assumed power. Cromwell was the glue that held the new government together. According to the Instrument of Government, Cromwell, as Lord Protector, was the "supreme legislative authority of the Commonwealth of England." 88 The Lord Protector was a dictatorship. A Council of State continued in the Instrument of Government as a check on the Lord Protector's power, but it was not much of a check. The government changed further in June 1657 when Cromwell accepted an amended version of the "Humble Petition" from Parliament. The original petition tried to make Cromwell King of England, but the army did not allow Cromwell to accept this invitation. Hence, the amended version was accepted. So, uncertainty reigned in England throughout the Interregnum, as no long term constitution could be agreed upon.

Oliver Cromwell died on September 3, 1658. Shortly before his death, the House of Commons excluded some of Cromwell's supporters. Also, growing tension existed between Cromwell and Parliament. Cromwell's death was the end of the constitutional experiments by Parliamentarians. His son Richard was a poor, leader and his succession as Lord Protector

\footnotetext{
${ }^{87}$ Blair Worden, The Rump Parliament, 92.

${ }^{88}$ Ibid., 308.
} 
exacerbated the political situation in England that had started to deteriorate under his father. ${ }^{89}$ The Council of State would not accept the Instrument of Government nor the Humble Petition because neither had been approved by a full parliament: thus, the Council of State called new elections for a new parliament in January 1659.

Richard Cromwell's ineffectiveness as a leader was due in fact to his being at the mercy of the army. He was forced to dissolve Parliament and agreed to the army's demand to reconvene the Rump Parliament in April 1659. Historian Smith argued that the Rump Parliament "refused to recognise the Protectorate and demanded Richard's resignation and the restoration of the Commonwealth. Isolated from both the Rump and the Army leadership, Richard resigned on 24 May."90 Quick successive failures in attempts to have stable constitutional governments between January 1659 and October 1659 created massive instability. Richard Cromwell's abdication was a serious problem for England because England seemed leaderless. The problem was so serious that Virginia adopted a new constitution in 1660 that gave it complete independence from England because Virginia did not know who was sovereign in England. The first section of the new 1660 Constitution said that the Virginia General Assembly, "by the late frequent distractions (whereas God in his mercy putt suddaine period to) there being in England noe resident absoute and gen'll. confessed power."91

The Rump Parliament required the support of the army in order to maintain legitimacy. The dysfunction of the revived Rump Parliament and its inability to bring about constitutional

\footnotetext{
${ }^{89}$ Ibid., 305.

${ }^{90}$ Smith, The Stuart Parliaments, 144.

${ }^{91}$ Hening, Hening's Statutes, 530.
} 
order forced the army to institute a Committee of Safety to govern England, and, so, the army dissolved the Rump Parliament.

The country was on the verge of political collapse without a stable functioning government and no true leader. A man by the name of George Monck, who was the commander of the Army in Scotland, decided to use his forces to bring stability to a situation resembling what Smith called "growing anarchy." ${ }^{\prime 2}$ Monck revived the Long Parliament in February 1660. It was these men who wanted to negotiate with Charles I when he was a captive of Parliament in 1648. It was no wonder that they were in favor of restoring the monarchy and began negotiating with Charles II. ${ }^{93}$ The members of the Long Parliament wanted a solution that involved both Parliament and King, which was the same solution that they still wanted 11 years later. The Long Parliament called for elections and dissolved itself on March 16, 1660, in order to have a new Parliament assemble with the sole purpose to call Charles II home. ${ }^{94}$

The issue of the day was that people wanted a "full and free Parliament." 95 The members of Parliament believed that a "full and free Parliament" would result in the political stability of England. Charles II knew that the people of England wanted a "full and free Parliament," so, he wrote the Declaration of Breda on April 4, 1660. Charles II was still in exile in the Netherlands and had found out that Monck was in charge of Parliament and that his army was sympathetic to him. Charles II wrote the Declaration of Breda to let Parliament and England know that he was

\footnotetext{
${ }^{92}$ Ibid., 145.

${ }^{93}$ Ibid., 145.

${ }^{94}$ Robert Wilcher, The Writing of Royalism 1628-1660 (New York: University Cambridge Press, 2001), 348.

${ }^{95}$ Gardiner, The Constitutional Documents, 466.
} 
reasonable, forgiving and desired a stable solution that would allow Parliament to exist, if he were allowed to return.

Charles II agreed that a solution between King and Parliament could be achieved. In Charles II's Breda Declaration, he agreed to “ordaining that henceforward all notes of discord, separation and difference of parties be utterly abolished among all our subjects, whom we invite and conjure to a perfect union among themselves, under our protection, for the resettlement of our just rights and theirs in a free parliament, by which, upon the word of a king, we will be advised."96 Charles II appealed to the people's desire for political order and a free Parliament; therefore, a pro-Royalist majority was elected to Parliament, which assembled with the House of Lords on April 25, 1660.

The two houses declared, on May 8, 1660, that "it can no way be doubted but that His Majesty's right and title to his Crowns and kingdoms is and was [in] every way completed by the death of his most royal father, without the ceremony or solemnity of a proclamation." 97 This Parliament declared that Charles II was truly King of England upon his father's last breath. Charles II was restored to the throne and transitioned England back into a constitutional monarchy. The political order of the House of Commons, the House of Lords and the Crown were all restored. The political trinity was reestablished. ${ }^{98}$ England finally had political stability at last.

\footnotetext{
${ }^{96}$ Kenyon, The Stuart Constitution, 332.

${ }^{97}$ Smith, The Stuart Parliaments, 146.

${ }^{98}$ Ibid., 146.
} 


\section{Chapter III: Virginia's Solution to England's Crisis}

Parliament informed Berkeley of Charles I's execution seven months after the fact. ${ }^{99}$ Parliament asked Berkeley to bring Virginia into the Commonwealth, but he refused and instead wanted royalist soldiers to migrate to Virginia in order to use Virginia as a loyalist outpost against Parliament. Berkeley was so upset at the news of the execution of the king that he gave a speech against Parliament denouncing its execution of Charles I. Parliament received this remonstrance in early 1650, which confirmed Virginia's hostility towards the Commonwealth. ${ }^{100}$ Berkeley made it clear that Virginia would not join the Commonwealth. An example of Berkeley's loyalty to Charles II, he wrote Charles II on mainland Europe sometime in 1649 when he asked him to get rid of Claiborne as Treasurer. Together, Berkeley continued to try and communicated with Charles II over the functions of government, even though Charles II was in exile. ${ }^{101}$ Parliament had to force Virginia into the Commonwealth because Virginia made its intentions clear.

At the same time, the Virginia General Assembly responded similar to Berkeley and passed an act that declared its disgust towards Parliament for the execution of Charles I as well as announced its loyalty to Charles II. The General Assembly said that Parliament's actions were "unparalel'd treasons, perpetrated on the said King."102 An act passed by the General Assembly on the October 10, 1649 declared Charles II sovereign ruler of Virginia. ${ }^{103}$ This step was necessary because the General Assembly needed to recognize a source of legitimacy with the

\footnotetext{
${ }^{99}$ Billings, The Papers of Sir William Berkeley, 105.

${ }^{100}$ McIlwaine, Jounrals of the House of Burgesses, 75.

${ }^{101}$ Billings, The Papers of Sir William Berkeley, 88.

${ }^{102}$ Hening, Hening's Statutes, 360.

${ }^{103}$ Ibid., 360 .
} 
death of its king, which was a natural step for the Virginia General Assembly to take under normal circumstances. The Virginia General Assembly chose to side with Charles II as it fit its tradition and followed the lead of its Governor.

Parliament in England now had a serious problem: Charles II conducted official government business with Berkeley in Virginia, as part of his government-in-exile in Breda, Netherlands. Charles II even sent a commission to Virginia on June 3, 1650 that placed sixteen men on the Council of State and maintained Berkeley as governor. ${ }^{104}$ In other words, he reaffirmed the present government in Virginia that his father had put in place, so nothing changed except that Charles II was not in England, and Parliament did not accept this commission as lawful. This commission was written in the "second year of our Raign Anno Domini."105 Charles II thus, acted as king, and both Berkeley and the Virginia General Assembly accepted his government as the lawful government, not Parliament.

Charles II's commission granted the Council of State and Governor the same powers and authority that the previous government had under Charles I. The commission read in part, [The] full power and authority to performe and execute the place power and authority incident and belonging unto a Governor and Councill of Virginia respectively, and to direct and Govern, ... according to the laws and Customs of Our Kingdom of England and to observe and keep them in their intire and due obedience to us and Our Royall Government. ${ }^{106}$

Parliament had made any mention of the monarchy or royal family illegal: so, this commission was in direct opposition to the Commonwealth. Charles II actively engaged in the legal and practical functions of government in protest to Parliament's claim to supreme authority.

\footnotetext{
${ }^{104}$ Billings, The Papers of Sir William Berkeley, 94.

${ }^{105}$ Ibid., 94 .

${ }^{106}$ Ibid., 92 .
} 
The Commission further stated, "AND WHEREAS Wee are willing to give all incouragement to that Plantation and Colony, and for the better maintenance on Government thereof are minded that Our People there shall be regulated and Ordered as well in Ecclesiasticall as Temporall Government according to the laws and Statutes of the Realm of England which wee purpose to Establish there."107 Between 1649-1652, Virginia followed the laws of the monarchy as if nothing had actually changed in England. This period ended because Parliament did not tolerate a disloyal Virginia.

\section{Virginia Surrenders}

The fleet sent by Parliament with the four Commissioners arrived in Virginia in January 1652. Berkeley gathered a force of 1,000 militia to meet the fleet at Jamestown. Berkeley was determined to have a strong show of force in order to negotiate favorable surrender terms. His first goal was to maintain credibility with Charles II because he saw Charles II as the rightful ruler of England. Berkeley did not want Charles II to think that he had allied himself with Parliament, and he wanted Charles II to think that he was being a good steward of Virginia on behalf of the King. ${ }^{108}$ Berkeley's second goal was to keep Virginia's General Assembly intact and to keep Parliament's hand out of Virginia's affairs as much as possible. ${ }^{109}$ Little did Berkeley know that the commissioner's instructions allowed favorable terms. Combined

\footnotetext{
${ }^{107}$ Ibid., 91.

${ }^{108}$ Billings, A Little Parliament, 31.

${ }^{109}$ Ibid., 31.
} 
together, Berkeley's show of force and Parliament's instructions gave Virginia favorable terms. Berkeley succeeded in preserving Virginia's political order because Parliament had allowed it. Virginia surrendered to Parliament on March 12, 1652, which caused a constitutional crisis and meant that Virginia's colonial government had to change. ${ }^{110}$ Charles I instituted the present constitution, but it was an illegal constitution after the surrender because it recognized the monarchy as Virginia's supreme authority. Just like the old constitution, Berkeley was forced out of power. Virginia was not allowed to have a Governor that refused to recognize the Commonwealth as its new sovereign.

The most important outcome of the surrender was the legal continuance of the General Assembly. The surrender document said, "secondly, that the Grand Assembly as formerly shall convene and transact the affairs of Virginia, wherein nothing is to be acted or done contrarie to the government of the common wealth of England and the lawes there established."111 The instructions and the surrender document gave Virginia permission to write a new constitution that recognized the Commonwealth as its supreme authority and allowed it to keep its government institutions. The political agreement between the Commissioners and Berkeley manifested itself into the 1652 Constitution. The surrender had to give Virginia favorable terms in order for selfgovernment to have been an option in Virginia.

\section{The 1652 Constitution}

\footnotetext{
${ }^{110}$ McIlwaine, Journals of the House of Burgesses, 79.

111 Ibid., 363.
} 
Parliament had created multiple crises throughout the Civil War and the Interregnum that Virginia had to find solutions to that met its local needs. As made clear, the first such crisis was the surrender in 1652 to Parliament. Virginia's solution was the 1652 Constitution, which was a new constitution that turned the General Assembly upside down. The House of Burgesses, as a result of Berkeley's bicameralism, made the House of Burgesses jealous of its independence from the Council of State. This jealousy of its new political powers was made clear in the 1652 Constitution as a solution to the problems in England.

The House of Burgesses' power to elect all public officials was the solution that the 1652 Constitution provided Virginia. The 1652 Constitution said, "it is agreed and thought best for the government of this country by the Governor, Council and Burgesses that the right of election of all officers of this colony be and appertain to the Burgesses the representative of the people."112 Previously, it was the Governor's power to appoint, but now the House of Burgesses had this power as "the representative of the people."113 Now, the House of Burgesses had the power to keep the Governor and the Councilors accountable to them through elections, which was a complete reversal from when the Governor had complete control in Virginia.

Although the 1652 Constitution gave Virginia some autonomy, it was quite clear that Virginia's new sovereign was Parliament. The 1652 Constitution, found in Hening's Statutes, stated that the new men selected as members of the Council of State, shall have power to execute and do right and equall justice to all the people and inhabitants of this collony according to such instructions as they have or shall receive

\footnotetext{
112 Ibid., 372.

113 Ibid., 372.
} 
from the Parliament of England and according to the knowne lawe of England; And the acts of Assembly here established. ${ }^{114}$

The 1652 Constitution gave Virginia authority to govern itself with its own laws, but it recognized its laws were not allowed to conflict with the new laws of England. This clause in the 1652 Constitution was Virginia's immediate solution to its political crisis and established as law that the Council of State had to recognize the laws of Virginia that placed political authority in Virginia within the House of Burgesses. Virginia’s autonomy and Parliament's vague instructions allowed the House of Burgesses to fill the power vacuum left by Parliament.

The power to elect the Governor and the Councilors was how the House of Burgesses developed into a powerful body because it was how the House of Burgesses gained all of its other powers. The Governor and the Council became accountable to the House of Burgesses for the first time. This change in constitutional structure would not have occurred without the surrender and the burgesses being singled out by Parliament as men who were "chosen by the planters." "15 The instructions by Parliament put power within the House of Burgesses, but it was strategic because it was the only institution that historically picked its members from within Virginia, not chosen by people in England.

The only power that the House of Burgesses did not take was the power to call elections. That was a power reserved for the Governor. The precedent and tradition of an executive that called elections dated back to the Great Charter. ${ }^{116}$ This precedent might have been the reason why the executive retained this prerogative, but a more likely reason is be that the House of

\footnotetext{
114 Ibid., 372.

115 Sainsbury, Calendar of State Papers, 361.

116 Billings, A Little Parliament, 173.
} 
Burgesses only sat in session for a temporary periods of time and then dissolved. When the House of Burgesses was dissolved, it was not capable of convening itself. House elections required an order for elections by the Governor when the House of Burgesses was out of session. It turned the political tables upside down, but kept some resemblance of its former political structure.

\section{The Interests of Virginia's Merchant-Councilor Class}

Economics and money drove politics throughout the Interregnum. The merchantcouncilor faction lead by Bennett, Claiborne and Mathews controlled the Council of State and Governor. This group of elite Virginians were socially and commercially connected with the powerful merchant guilds in London that helped these men maintain a monopoly on tobacco exports from Virginia to England. Bennett and Claiborne were two of the four commissioners sent by Parliament to force Virginia into surrender. This political faction had economic interests in excluding the Dutch from Virginia's tobacco markets. The Navigation Act played into the faction's favor because it helped them gain a trade monopoly with England. This faction was powerful and was dominant because Parliament backed them because of their loyalty to Parliament. Both parties benefited from each other.

The merchant-councilors controlled the Council of State after the surrender and managed to get an ally elected Speaker of the House of Burgesses, Walter Chiles. ${ }^{117}$ One wonders if the members of the Claiborne-Mathews faction enticed the constitutional structure in 1652 that

\footnotetext{
${ }^{117}$ Billings, A Little Parliament, 195.
} 
favored the House of Burgesses. The House elected Bennett the first Governor and Claiborne the Secretary of the colony. ${ }^{118}$ Bennett also tried to recommend a member of his faction as Speaker at a future date, to which the House of Burgesses did not take kindly because it saw Bennett involving himself in its own affairs. ${ }^{119}$ Later, the House elected Mathews agent to Parliament to speak on the General Assembly's behalf as a lobbyist or ambassador. ${ }^{120}$ These men held prominent positions in society that they only managed to gain through the House of Burgesses' power to elect public officers. It is fair to speculate that, as commissioners, they would have set up a system of government that would be favorable to them.

After the House established the 1652 Constitution, two things happened in regards to the Navigation Act. First, the colonies in America became important to the mother country. However, at that time, England did not care about the details of government in Virginia, but they cared about the trade in Virginia. The Navigation Act created a trade monopoly with England for the Claiborne-Mathews faction. Second, the Navigation Act created two different factions in the House of Burgesses were not based on religion, but money. The smaller planter class wanted to trade with the Dutch because the Claiborne-Mathews faction was connected with the London merchant elites that wanted to squeeze the smaller planters out of Virginia's tobacco market. The way to accomplish this goal was to prevent trade with the Dutch through the Navigation Act. ${ }^{121}$ The issue of money was so strong that Parliament passed a law in April 1652 that prohibited anyone in England from planting tobacco. Records from the Calendar of State

\footnotetext{
${ }^{118}$ McIlwaine, Journals of the House of Burgesses, 82.

119 Ibid., 86.

${ }^{120}$ Ibid., 92.

${ }^{121}$ Robert Brenner, Merchants and Revolution: Commercial Change, Political Conflict, and London's Overseas Traders (New York: Verso, 2003), 629.
} 
Papers state that a "petition of merchants, adventurers of London, trading to Virginia and other foreign plantations, to the Council of State. By Act of Parliament of 1 April 1652, sowing tobacco in England was prohibited." 122 Virginia had an interest in this law because it meant higher profits for colonists, by reducing competition within the market. The General Assembly paid Mathews during the proceedings of 1653 as "our agent," ${ }^{123}$ which suggested a personal representation for the General Assembly.

The General Assembly had an agent in England as early as December 1653 when Mathews petitioned the English Council of State about the dispute with Maryland over Kent Island. This island was in the Chesapeake Bay that the Claiborne-Mathews faction wanted from Maryland because of the fur trade interests that they had on the island. ${ }^{124}$ It was known that at least by March 1654 that Mathews petitioned the English Council on tobacco crops in England as well. He wanted Parliament to revive the law that prevented the planting of tobacco crops in England, so he filed a petition to the Assistants to the Committee of the Council for the Treasuries that stated that he had "reasons why it will be of very ill consequence if an Act of Parliament now in force, prohibiting the planting of tobacco in England is not revived before the tobacco is transplanted out of the hot beds." 125 If England was allowed to grow tobacco, it not only hurt the faction, but also the smaller land owners too. The Claiborne-Mathews faction was powerful enough and possessed enough political clout that members of its faction were chosen to petition Parliament directly.

\footnotetext{
122 Sainsbury, Calendar of State Papers, 405.

${ }^{123}$ McIlwaine, Journals of the House of Burgesses, 92.

124 Grizzard. Jamestown Colony, 51.

125 Sainsbury, Calendar of State Papers, 415.
} 
The fact that the General Assembly petitioned Parliament in person directly through an “agent" was a significant change within the relationship between Virginia and England and highlighted the importance of commerce to Virginia and why Virginia needed a functioning government throughout the Interregnum. It was an unprecedented step that an agent became a conduit for communication between the mother country and the colony. The General Assembly adopted new political techniques that met its local needs as a result of its transition towards selfgovernment. The activity of the agent demonstrated a solution for Virginia sought by Virginians.

\section{Virginia's Constitutional Crisis}

In 1658, Virginia had its own political crisis because the 1652 Constitution was tested. This crisis was the second to originate in Virginia after the Indian War of 1644. It involved a conflict between the Council of State and the House of Burgesses that resulted in both the impeachment of the members of the Council of State and the Governor. The result of this conflict represented the strength of Virginia's self-government because the 1652 Constitution remained intact.

The conflict made news in England because merchants were afraid that they would be unable to trade with Virginia, if it descended into political chaos. The English Council of State in August 1658 said,

order of the Council of State. Upon petition of divers merchants and planters of Virginia setting forth the distracted state of that colony and the inconvenience that may ensue if the ships now going should depart without some declaration concerning the settling of the 
government there, and praying that the present Governor and Council may be directed to apply themselves to the peaceable management of affairs. ${ }^{126}$

This letter illustrates the seriousness of the conflict between the Virginia Council of State and the House of Burgesses. Also, this letter highlights the importance of how commerce required a functioning government.

One of the instigators of this conflict was the son of the agent, Samuel Mathews, Jr. He was a young man when he became governor and he was probably a compromise choice between the House of Burgesses and the Claiborne-Mathews controlled Council of State in December 1656 as the third Interregnum Governor. ${ }^{127}$ It was not a smart move, though, because he upset the House of Burgesses when he tried to dissolve the House of Burgesses. This illegal action was the second time that an elected Governor upset the House of Burgesses. Earlier, in 1653, Governor Bennett meddled in the House of Burgesses' business by trying to suggest his friend from the Claiborne-Mathews faction, Walter Chiles, as Speaker of the House. ${ }^{128}$ The House of Burgesses was jealous of its powers and did not take kindly to interferences by the Governor. The House of Burgesses was a political body that had matured into an institution that could win a constitutional battle with the other part of the General Assembly. ${ }^{129}$

The Constitutional Crisis of 1658 started with the Council of State's desire to revive a law that prohibited paid lawyers in the colony's courts. The House of Burgesses petitioned Governor Mathews and the Council for their views on this law. Claiborne responded on March 23, 1658: "the answer of the Governor and Council to the House's Message about the lawyers.

\footnotetext{
126 Ibid., 468.

${ }^{127}$ Billings, A Little Parliament, 35.

${ }^{128}$ McIlwaine, Journals of the House of Burgesses, 86.

${ }^{129}$ Kukla, Political Institutions in Virginia, 182.
} 
The Governor and Council will consent to this proposition so farr as it shall be agreeable to Magna Charta."130 No one knows why Virginia's constitutional struggle began over this ambiguous response, but it was obvious that the House of Burgesses was not impressed by the Council of State's invocation of Magna Carta. ${ }^{131}$

The House of Burgesses decided the best way to react was through the creation a committee to draw up a response to the Council. The committee replied on March 25, to the first wee have considered Magna Charta and wee cannot discerne any prohibition conteined therein but that these propositions may pass into lawes. It was resolved in two former Assemblyes that it was not onely necessary but that they had power to make lawes for that purpose, as appears by two acts of Assembly now upon record. ${ }^{132}$

On March 26, the House of Burgesses voted to eject lawyers contrary to the wishes of the Council because of the precedent set in two earlier sessions of the General Assembly. Its not known why the issue of lawyers was such a tense subject between the Council and the House, but the young governor decided that it was time to dissolve the House of Burgesses, which was a major political mistake.

On April 1st, the Governor and the Council responded to the House of Burgesses when it declared that "the Governour and the Councill for many important cases do think fitt hereby to declare, That they do now disolve this present Assembly, And that the Speaker accordingly do dismiss the Burgesses."133 The same day, the House of Burgesses quickly responded, the House humbly presenteth, That the said disolution as the case now standeth is not presidentall neither legal according to the lawes, now in force, Therefore wee humbly

\footnotetext{
${ }^{130}$ McIlwaine, Journals of the House of Burgesses, 106.

${ }^{131}$ Ibid., 106.

132 Ibid., 106.

133 Ibid., 109.
} 
desire a revocation of the said declaration, especially seeing wee doubt not but speedinly to finish the present affaires to the satisfaction of your honour and the whole country. ${ }^{134}$

The constitutional battle had begun and the battle lines drawn over the issue of who had the political power within the colonial government to dissolve the House of Burgesses under the 1652 Constitution.

The issue of who had the power to dissolve the House had the potential to destroy the 1652 Constitution, which is why the House of Burgesses tried to give the Council a way to save face by humbly asking the Council to revoke its decision. The Council wanted the question of whether the Governor had the power to dissolve the House of Burgesses answered. They did not want a situation where a compromise was reached, but the constitutional issue still remained. It was a mistake to push the issue because the House of Burgesses defeated them. ${ }^{135}$

The following day, April 2nd, the House of Burgesses made attempts towards uniformity in its approach towards the Council. The burgesses made it illegal for a member of the House of Burgesses to be absent from their proceedings. They wanted full attendance of their membership, so they passed a resolution with strong language that would censure a member of the House as one who had betrayed the trust of Virginia. ${ }^{136}$ Another step towards uniformity was that the Speaker of the House was not allowed to sign anything without the consent of the majority of the House of Burgesses. ${ }^{137}$ Further, the House of Burgesses made it law that all of the members had to take an oath of secrecy. ${ }^{138}$ The House of Burgesses wanted to speak with

\footnotetext{
134 Ibid., 109.

135 Kukla, Political Institutions in Virginia, 195.

${ }^{136}$ McIlwaine, Journals of the House of Burgesses, 110.

${ }^{137}$ Ibid., 110.

${ }^{138}$ Ibid., 110.
} 
one voice throughout this constitutional crisis in order to protect its constitutional prerogatives. Governor Mathews did not foresee the efforts that the House would take to defend its power to consent to its own dissolution.

The Council wanted to send the issue to the Lord Protector, Oliver Cromwell, to mediate because it realized that it was fighting a losing battle. The Council wanted to find a quick solution as the House of Burgesses had previously suggested, but they thought it was necessary to involve the Lord Protector. ${ }^{139}$ The only reason that the Council wanted to put the constitutional issue before the Lord Protector was because they knew they did not have the political capital to win the dispute in Virginia. The 1652 Constitution turned the tables on the Governor as a result of the Civil War and Mathews might have tried to find a way to regain some of his predecessor's former political power.

The House of Burgesses responded that it did not favor involving the Lord Protector. The House of Burgesses had a long list of issues that it wanted to continue to work through during the session and the burgesses did not want to get wrapped up into a long constitutional dispute with the Council. The House tried to let the Council save face one more time.

On the same day still, April 2nd, the Council did not want to revoke its decision to dissolve the House. The Council and the Governor responded, "upon your promise received of the speedy and happy conclusion, Wee revoke the declaration for the dissolution of the Assembly, And referre the dispute of the power of dissolving and the legality therefo to his Highnesse the Lord Protector. ${ }^{140 "}$ The Council had pushed its luck by still insisting that the Lord Protector mediate the issue. They did not recognize nor want the House of Burgesses to have

\footnotetext{
${ }^{139}$ Ibid., 110

${ }^{140}$ Ibid., 110.
} 
consent over its own dissolution if they insisted upon the Lord Protector's involvement a second time. The House of Burgesses knew that the agent in London was a member of the same Claiborne-Mathews faction that dominated the Council, so the agent would be biased towards the Council. It was in the House's interests to keep the dispute in Virginia and not risk involving Cromwell because they would have had to submit to his decision. The House of Burgesses did not want to jeopardize its power

The House of Burgesses utilized committees well and it decided to use one to draft a proper response based upon studied precedent. The House created a committee called the "Committee For Vindication and Manifestation of the Assemblyes Power" and that committee wrote a draft response to the Council and the Governor. Leading Burgesses were on this committee and they put forth a proposal to the House of Burgesses that stated, "wee have considered the present constitution of the government of Virginia and do propose, That wee find by the records, The present power of government to reside in such persons as shall be impowered by the Burgesses (the representatives of the people) who are not dissolvable by any power now extant in Virginia, but the House of Burgesses."141 A final declaration by the House of Burgesses based upon the recommendation of the committee report ordered that "all former election of Governour and Council be void and null." 142 This declaration was an impeachment of the Governor and Councilors from public office.

The House decided to utilize its power of election of all public officers in Virginia to enforce its decision to prevent the Council from dissolving them. The Governor was accountable to the body that elected him; therefore, by impeaching Governor Mathews and the Councilors,

\footnotetext{
${ }^{141}$ Ibid., 111.

142 Ibid., 111.
} 
the Burgesses won the constitutional battle. Oddly though, the Burgesses reelected Mathews, Jr. as Governor in the same declaration, as if they only wanted to teach him a lesson and not plunge Virginia into chaos. The House of Burgesses only desired to find an answer to the constitutional question and did not want a second constitutional overhaul. The Governor made an illegitimate claim of power, and he paid for it dearly. ${ }^{143}$

All public officers on the Council of State, including the Secretary of the Colony were impeached. Just like the Governor, the Secretary was also a member of the Council. The House of Burgesses required that Claiborne, as the impeached secretary of the colony, hand the records of the colony over to the Speaker of the House of Burgesses because the House abolished his position as Secretary. The House of Burgesses ordered its Sergeant-At-Arms to enforce this order, which meant that the House of Burgesses controlled the entire government of the colony of Virginia. The 1652 Constitution remain intact and survived the constitutional test when the burgesses followed through on their power to elect a Governor and Councilors, and did not rule the colony by itself. The House reelected all the men on the Council of State that took part in the crisis and the House also reelected Mathews, Jr. as Governor again. The House of Burgesses did not want to rule by itself because the impeachment of the Governor and the members of the Council was a lesson, not an overhaul. ${ }^{144}$

To prevent a future constitutional crisis, the House of Burgesses ordered "that whereas the supreame power of this country of Virginia is by this Grand Assembly declared to be resident in the Burgesses, the representatives of the people." 145 This simple order concluded the crisis

\footnotetext{
${ }^{143}$ Kukla, Political Institutions in Virginia, 200.

144 Ibid., 200.

${ }^{145}$ McIlwaine, Journals of the House of Burgesses, 111.
} 
because it codified in law that that the supreme power in Virginia rested in the House of Burgesses. The Burgesses still recognized England as the ultimate supreme authority over Virginia, but they were supreme in Virginia amongst Virginians through self-government. ${ }^{146}$

\section{Chaos in Death: Governor Mathews's Passing in 1660}

In January 1660, Governor Mathews died, and no provision existed in the 1652 Constitution for a Lieutenant Governor or a process to appoint an executive officer to call elections for the House of Burgesses when it was out of session. ${ }^{147}$ This problem was the third crisis that originated in Virginia because the House of Burgesses was unable to legally convene itself without the call for elections. No process existed in the 1652 Constitution to appoint a Governor while the House of Burgesses was out of session. Virginia did not have a mechanism in its constitution to solve this crisis. Virginia would not turn to England to find its solution. Once more, Virginians found solutions to their own problems, which was another sign that Virginia had achieved self-government.

When Virginia was a royal colony, the Councilors had authority under a royal commission to appoint one of themselves acting governor until the King could appoint a new Governor. ${ }^{148}$ Governor Mathews' death was unexpected and created a major problem because the royal commission was null and void according to the surrender document. The House of Burgesses sat at the call of the Governor, but Mathews died at a time when the General Assembly

\footnotetext{
${ }^{146}$ Kukla, Political Institutions in Virginia, 204.

${ }^{147}$ Billings, A Little Parliament, 41.

${ }^{148}$ Ibid., 41.
} 
was in recess. It was dissolved and unable to elect a new Governor. The colonial government was in a real dilemma. ${ }^{149}$

Not much information exists today that describes how Berkeley was selected to be governor again. He seems to have been a compromise choice between the Claiborne-Mathews faction and the smaller planters within the House of Burgesses. Berkeley was kicked out of power by the surrender eight years earlier. It was believed that Claiborne and the Council of State persuaded Berkeley to take the job as governor, but he had to agree to reconvene the General Assembly in order to allow the General Assembly to vote him into office. Berkeley knew, if he became Governor, he would put himself in a difficult situation. He had been ousted as governor under those in authority in England, but he did not want to upset Charles II by becoming governor under a hostile regime. ${ }^{150}$

Berkeley overcame his two biggest fears and the House presented Berkeley with a set of demands. The conditions that the Burgesses placed on Berkeley did not appeal to him. The House wanted him to call an assembly every two years and recognize that it had a right to consent to its own dissolution. They wanted him to recognize that the Burgesses held supreme political power in Virginia and to recognize the established laws of Virginia: the House of Burgesses did not want to lose its constitutional gains, but Virginia needed a Governor. Eventually, Berkeley relented to these demands and the House elected Berkeley Governor in March 1660. ${ }^{151}$

\footnotetext{
${ }^{149}$ Ibid., 41.

${ }^{150}$ Ibid., 41.

${ }^{151}$ Hening, Hening's Statutes, 530.
} 


\section{The Sovereignty Conundrum of 1660}

Virginia's 1660 declaration of absolute sovereignty started when Cromwell died on September $3,1658 .{ }^{152}$ His death began another constitutional crisis for Virginia. His son, Richard Cromwell came to the throne as his successor, but his rule as Lord Protector was cut short by the army. Confusion existed in Virginia over who was sovereign in England after Richard Cromwell's abdication in May 1659. ${ }^{153}$ The distance between England and Virginia probably added to the uncertainty that was felt in Virginia because having a sovereign authority that legitimated the Virginia General Assembly was important to the Virginians and had been important to the Virginians even since Charles I's execution in 1649. With news of royalist uprisings, Virginians questioned who was in power in England. It was a tense time for the General Assembly in regards to its relationship with England because of the uncertain events followed one another like a train from late 1659 to early 1660.

In March 1660, Berkeley was not only the new governor, he resided over a session of the General Assembly that pushed the envelope further than what had happened in the Constitutional Crisis of 1658. In 1658, the House claimed supreme power within Virginia, but the General Assembly in 1660 did something completely different under Berkeley's reluctant leadership. The situation in England was chaotic enough that no one in Virginia knew who was sovereign in England in March 1660. No one in Virginia knew who ruled England after Richard Cromwell abdicated, so the Virginia General Assembly decided to recognize itself as sovereign. The General Assembly passed into law,

\footnotetext{
${ }^{152}$ Mcllwaine, Journals of the House of Burgesses, 115.

${ }^{153}$ John Anthony Butler, A Biography of Richard Cromwell, 1626-1712 (Lewiston: Edwin Mellen Press, 1994), 105.
} 
whereas by reason of the late frequent distractions (which God in his mercy putt a suddaine period to) there being in England noe resident absolute and gen'll. confessed power; Be it enacted and confirmed, That the supreame power of the government of this country shall be resident in the Assembly, And that all writts issue in the name of the Grand Assembly of Virginia, until such a comand and comission come come out of England as shall be by the Assembly adjudged lawful. ${ }^{154}$

This act was taken not as a means to seek independence, but to bring about stability once more. Virginia wanted to turn to England, but it could not because no one in England knew who was sovereign either.

Berkeley lead Virginia towards absolute sovereignty according to a speech that he gave before accepting the governorship. He did not want to upset Charles II and worried what he might think. Berkeley also did not want to upset Parliament in case they kept power and thought that Berkeley might have tried to undermine the surrender that he had agreed to in $1652 .{ }^{155}$ As Kukla said it, this declaration of absolute sovereignty residing in the General Assembly was an attempt "merely to stay afloat amid a political gale." 156 The actions of the General Assembly in 1660 were much different and more significant than the actions of the House of Burgesses in 1658. The General Assembly in 1660 no longer recognized England as the supreme authority, which made Virginia a Commonwealth for a brief period of time until the situation in England was resolved. This declaration of self-government served as a constitutional life raft.

\section{The Restoration of Charles II}

\footnotetext{
${ }^{154}$ Hening, Hening's Statutes, 530.

${ }^{155}$ Billings, The Papers of Sir William Berkeley, 119.

${ }^{156}$ Kukla, Political Institutions in Virginia, 208.
} 
Berkeley helped Virginia weather the storm of uncertainty created by England, but he also helped bring Virginia back into the kingdom ruled by Charles II. Charles II was restored to the throne in May 1660, but it was not until the fall of 1660 that the news of the restoration and Virginia's return as a royal colony reached Virginia. On September 20, 1660, an excited Governor Berkeley sent a proclamation to all the county court houses announcing Charles II was King of England. It read, in part, "that imeadiately upon the decease of the late Sovereigne Lord King Charles, The Imperiall Crowne of the Realme of England \& of all the Kingdomes, Dominions, \& rights belonging to the Same did by Inherent Birthrights, \& lawfull \& Undoubted Succession, descend \& come to his most Excellent Majestye Charles the Second."157 Berkeley ushered in the change that established Charles II's rule over Virginia.

It was Charles II's commission, from July 1660, though, that recognized Berkeley as Governor based upon his original 1650 commission. Charles II acted as if nothing had happened in Virginia between 1652-1660. Berkeley then, in turn, kept all public officers in place. Work had to be done to finish the transition, and he did not want to add further change to a fluid situation. The 1652 Constitution needed to be undone and reversed. The period of selfgovernment and freedom was over in Virginia. Charles II now ruled Virginia, and the constitution had to reflect that change. ${ }^{158}$

\footnotetext{
${ }^{157}$ Billings, The Papers of Sir William Berkeley, 129.

158 Billings, A Little Parliament, 42.
} 


\section{Conclusion}

Self-government in Virginia during the 1650s was a direct result of the English Civil War and the Interregnum. England was in political crisis between 1642 and 1660. The situation in England had a profound effect on Virginia because the two were linked, constitutionally and economically, in the early seventeenth century. ${ }^{159}$ The Virginia General Assembly experienced political freedom from England, but it still turned to England for legitimacy and instructions. Virginia was thrown into political confusion when Virginia's royal sovereignty ended as Charles I's head was severed from his body. The change meant that Virginia's relationship with England had to change too. The Commonwealth forced Virginia's surrender, and, for a time in 1660, it no longer turned to England. ${ }^{160}$ As a young colony, Virginia had to meet its local needs and weather the storm that brewed in England on its own. Virginia chose self-government as a means to an end in order to have political stability and a functioning government.

Chapter One provided an overview of the early history of the Virginia General Assembly, broken into two distinct periods. The first part was the creation of the colony and the development of its governmental structures under the Virginia Company of London. The result of the Company's oversight in Virginia was the completion of the Virginia General Assembly with the final addition of the House of Burgesses in 1619. ${ }^{161}$ The Company placed all the branches of the colonial government together. The form that Virginia's government took had its origin in this period. The Company's motivation for profit established Virginia's government, so that economic regulations and management decisions could be made more swiftly and effectively

\footnotetext{
${ }^{159}$ McIlwaine, Journals of the House of Burgesses of Virginia, 124.

${ }^{160}$ Hening, Hening's Statutes, 530.

${ }^{161}$ Horn, A Land As God Made It, 239.
} 
in Virginia. ${ }^{162}$ Understanding the origins of Virginia's government is critical to understand how the story of Virginia began.

The second phase was the colony's government under direct royal control. Virginia as a royal colony was not much different than under the joint-stock company, because Charles I retained the Virginia General Assembly. ${ }^{163}$ The result of Virginia as a new royal colony was that its constitution changed through royal commissions that granted the royal appointed governors more and more power. Charles I's inexperience and lack of vision for the usefulness of the Virginia General Assembly allowed the governors to have greater influence over the development of the body. Berkeley's split of the General Assembly into two separate bodies in 1643 proved important. ${ }^{164}$ The Virginia General Assembly under Charles I was, thus, a period of growth and maturation for the General Assembly.

Chapter Two explained how unstable the situation was in England. The result of the Civil War and the Interregnum on England was political uncertainty for England's government. The chapter laid out all the developments that caused political turmoil in England. This description of chaos in England was important to understand as it explained why the changes that Virginia made were necessary. Parliament made the people of England anxious as it made illegal decisions and forced political change that never stabilized into a functioning, long-term constitution. ${ }^{165}$ The chaos in England had to be described in order to demonstrate why Virginia responded the way it did to that chaos.

\footnotetext{
162 Billings, A Little Parliament, 6.

${ }^{163}$ McIlwaine, Journals of the House of Burgesses, 43.

164 Billings, A Little Parliament, 27.

165 Smith, The Stuart Parliaments, 145.
} 
Parliament destabilized England through its claim of sovereignty and its execution of Charles I, which likewise destabilized Virginia. It was important to show the early stages of the 1652 Surrender in Chapter Two because that decision by Parliament to force Virginia's surrender added further destabilization to Virginia. ${ }^{166}$ It was Parliament's choice to force the submission of the Virginia General Assembly, which resulted in Berkeley's removal as governor and the creation of the 1652 Constitution. Throughout Chapter Three, Parliament instigated change that Virginia did not want and this change effected Virginia. Parliament changed constantly between 1653-1660, which resulted in Parliament being out of touch with the needs of the Virginia General Assembly.

Chapter Three is the apex of the argument and the part of the thesis that explained Virginia's successful run at self-government. A clear contrast existed between the Virginia prior to the Interregnum and the Virginia of the Interregnum. Virginia had a new constitution that shifted the balance of power from the Council of State and the Governor to the House of Burgesses. ${ }^{167}$ Parliament's instructions placed the power in the Burgesses, as "representative of the people."168 This mantel of leadership made the House jealous of its powers, which resulted in a statute in the new 1652 Constitution that gave the House of Burgesses the power to elect all public officers. After the surrender, the House of Burgesses became the most powerful political institution in Virginia until the restoration of Charles II because it had the power to control the other parts of government. The 1652 Constitution made this change permanent throughout the Interregnum and resulted in Virginia's solution to the problems caused by England. Virginia

\footnotetext{
166 McIlwaine, Journals of the House of Burgesses, 79.

${ }^{167}$ Hening, Hening's Statutes, 372.

168 Sainsbury, Calendar of State Papers, 361.
} 
achieved self-government through the efforts of the House of Burgesses, as the representative of all free white men.

The three most memorable ways that Virginia exercised independence after 1652 were when the constitution was tested in 1658, Governor Mathews, Jr. died in 1660 and when Virginia claimed absolute sovereignty in 1660. First, in 1658, the Council of State attempted to dissolve the House of Burgesses, which was a unique threat to the constitution. ${ }^{169}$ It was an unconstitutional maneuver by the Council and it lost that political battle with the House of Burgesses. This constitutional fight was a result of self-government.

Second, Governor Mathews death resulted in a political crisis because Virginia had no public officer who could call elections. The General Assembly was out of session when Governor Mathews died, and it was the Governor's power to call elections and no one else. ${ }^{170}$ Virginians fixed the political crisis and did not turn to England for instructions. A full functioning self-government handled its own constitutional crisis, when it decided to elect Berkeley as Governor. ${ }^{171}$ This situation showed that Virginia was able to solve its own political crises too.

Third, in 1660, the General Assembly claimed absolute sovereignty, which was the result of the chaotic situation in England before the restoration. This claim of sovereignty was different than the claim of sovereignty in 1658 because the Virginia General Assembly no longer recognized any political authority over it in England. This claim was not a complete break form England, but Virginia believed it was important to have a source of legitimacy in order for the

\footnotetext{
${ }^{169}$ Kukla, Political Institutions in Virginia, 200.

${ }^{170}$ Billings, A Little Parliament, 41.

${ }^{171}$ Ibid., 41.
} 
General Assembly to exercise the functions of government in the name of that sovereign. ${ }^{172}$ England had no true sovereign, and Virginia wanted political stability as it was detached from the situation from England. This claim of sovereignty brought stability to Virginia in order to fulfill its local needs for a functioning government. Virginia found many solutions from its first solution, the 1652 Constitution.

Virginia's mid-seventeenth century history is significant. The Virginia General Assembly transformed from an institution built as a profit-creation tool and local conduit of English directive to a capable independent political body. This transformation was achieved as a result of the English Civil War and the Interregnum. Virginia would not have had a reason to seek selfgovernment if England was not consumed by political chaos. The problem for Virginia was that the Interregnum did not last forever. Charles II was restored to the throne in 1660 and the power structure that the Virginia General Assembly operated under before the surrender went back into effect. The 1652 Constitution and the General Assembly's claims to sovereignty ended in late 1660 with the restoration of Charles II.

The restoration ended Virginia's short period of self-government and, thus, ended the period of Virginia's history that deserves more attention. This time of self-government would not be seen again in Virginia until 1775.

${ }^{172}$ Hening, Hening's Statutes, 530. 


\title{
Bibliography
}

\author{
Primary Sources
}

Billings, Warren. The Papers of Sir William Berkeley 1605-1677. Richmond: Library of Virginia, 2007.

Billings, Warren M. The Old Dominion in the Seventeenth Century: A Documentary History of Virginia, 1606-1700. Chapel Hill: University of North Carolina Press, 2007.

Gardiner, Samuel R. The Constitutional Documents of the Puritan Revolution: 1625-1660.

Claredon: Oxford University Publisher, 1962

Hening, William Waller. The Statutes at Large; Being a Collection of All the Laws of Virginia from the First Session of the Legislature, In the Year 1619 Volume I. New York: R. \& W. \& G. Bartow, 1823.

Kenyon, J. P. The Stuart Constitution 1603-1688: Documents and Commentary. Cambridge: Cambridge University Press, 1986.

Kingsbury, Susan Myra. The Records of The Virginia Company of London: Documents I 1607-1622, Volume III. Washington, D.C.: US Government Printing Office, 1933.

McIlwaine, H.R. Journals of the House of Burgesses of Virginia 1619-1658/59. Richmond, VA: Library of Virginia, 1915

Sainsbury, W. Noel. Calendar of State Papers, Colonial Series, 1574-1660. London: State Department of Her Majesty's Public Record Office, 1860.

Smith, John, and John M. Thompson. The Journals of Captain John Smith: A Jamestown Biography. Washington, D.C: National Geographic Society, 2007.

\section{Secondary Sources}

Benians, E. A. Captain John Smith: Travels History of Virginia. New York: Cambridge University Press, 1908

Billings, Warren. A Little Parliament: The Virginia General Assembly in the Seventeenth Century. Richmond: The Library of Virginia, 2004. 
Billings, Warren M. Sir William Berkeley and the Forging of Colonial Virginia. Baton Rouge: Louisiana State University Press, 2004.

Boddie, John Bennett. Seventeenth Century Isle of Wight County Virginia. Chicago: Genealogical Publishing Company, reprinted 1994.

Brenner, Robert. Merchants and Revolution: Commercial Change, Political Conflict, and London's Overseas Traders. New York: Verso, 2003.

Bruce, Philip Alexander. Institutional History of Virginia in the Seventeenth Century Volume II. New York: G.P. Putnam’s Sons, 1910.

Butler, John Anthony. A Biography of Richard Cromwell, 1626-1712. Lewiston: Edwin Mellen Press, 1994.

Craven, Wesley Frank, Dissolution of the Virginia Company: The Failure of a Colonial Experiment. Gloucester: Peter Smith, 1964.

Craven, Wesley Frank, The Virginia Company of London: 1606-1624. Williamsburg: Virginia 350th Anniversary Celebration Corporation, 1957.

Gardiner, Samuel R. History of the Great Civil War 1642-1649 Volume I. New York: AMS Press, 1965.

Gardiner, Samuel R. History of the Great Civil War 1642-1649 Volume III. New York: AMS Press, 1965.

Gardiner, Samuel R. History of the Great Civil War 1642-1649 Volume IV. New York: AMS Press, 1965.

Greene, Jack P. Creating the British Atlantic: Essays on Transplantation, Adaptation, and Continuity. Richmond: University of Virginia Press, 2013.

Grizzard, Frank E. Jamestown Colony: A Political, Social, and Cultural History. Santa Barbara: ABC-CLIO, Inc., 2007.

Horn, James, A Land As God Made It: Jamestown and the Birth of America. New York: Basic Books, 2005.

Kukla, Jon. Political Institutions in Virginia. New York: Garland Publishing, 1989.

Smith, David. The Stuart Parliaments: 1603-1689. New York: Oxford University Press, 1999. 
Spurr, John, Anthony Ashley Cooper, First Earl of Shaftesburry 1621-1683. Farnham: MPG Books Group, 2011.

Taylor, Alan. American Colonies: The Settling of North America. New York: Penguin Books, 2001.

Tyacke, Nicholas. Aspects of English Protestantism C. 1530-1700. Manchester: Manchester University Press, 2001.

Wilcher, Robert The Writing of Royalism 1628-1660. New York: University Cambridge Press, 2001.

Worden, Blair. The Rump Parliament. Cambridge: Cambridge University Press, 1974. 